\title{
PEMBINAAN DAN PENDAMPINGAN PIMPINANAN KEPERAWATAN DALAM MELAKSANAKAN PERAN DAN FUNGSI MANAJEMEN PADA KEPALA RUANG DI RS PKU MUHAMMADIYAH SURAKARTA
}

\author{
Arum Pratiwi dan Yuni Wulan Utami \\ Jurusan Keperawatan - FIK \\ Universitas muhammadiyah Surakarta
}

\begin{abstract}
Role and function management must be done nurse manager in hospital. Nursing low manager one of leader which conduct the leadership role and function. The aim of the activity is improving duty of nurse low manager when they conducted leadership role and function. The participate in the activity are nurse low manager and primary nursing. The method of activity are lecturer, discusion, simulation and demonstration. The result of activity describe improving level of knowledge nurse low manager. In addition, nurse low manager also be able to demonstrate leadershif role and function managerial in their room.
\end{abstract}

Kata kunci: kepala ruang dan ketua tim, peran dan fungsi manajerial

\section{PENDAHULUAN}

\section{Analisis Situasi}

Rumah Sakit PKU Muhammadiyah Surakarta merupakan satu dari dua rumah sakit Islam swasta yang ada di kota Surakarta. Rumah sakit ini terdiri dari 3 poliklinik dan 10 ruang perawatan dengan kapasitas tempat tidur 168. Selama tahun 2008 BOR mencapai 90\%. Dilihat dari jumlah BOR yang tinggi dapat disim-pulkan bahwa rumah sakit ini banyak dikunjungi pasien. Jumlah tenaga keperawatan ada 199 orang dengan latar belakang pendidikan SPK 49 dan AKPER 150 orang Jumlah kepala ruang 10 orang dengan 20 koordinator shif dan ketua tim.

Kegiatan pelayanan dan asuhan keperawatan dilakukan perawat pelaksa-na mulai dari penanganan pasien yang berat (critical care) sampai pasien yang ringan (self care). Data catatan medis pasien menggambarkan $70 \%$ pasien masuk ke Unit Gawat Darurat dengan alasan sakit ringan sampai kegawat-daruratan. Tanggung jawab perawat berhubungan dengan kasus tersebut adalah pemberikan asuhan keperawatan yang efektif sesuai harapan pasien. Untuk mencapai tujuan tersebut seorang perawat harus mempunyai ilmu tentang bagaimana merawat pasien dengan self care sampai critis.

Pengelolaaan manajemen keperawatan yang dilakukan di rumah sakit PKU dari hasil observasi tentang peran dan fungsi pimpinan keperawatan, penatalaksanaan pasien dan supervisi oleh pimpinan keperawatan di rumah sakit PKU Muhammadiyah Surakarta dapat disimpulkan bahwa kinerja 
yang berhubungan dengan hal tersebut masih kurang profesional. Pimpinan kepera-watan belum melaksanakan hal tersebut secara prosedur normatif, pelaksananan hanya bersifat rutinitas. Hal ini belum dilakukan oleh supervisor atau kepala ruang sebab pengetahuan tentang hal ini belum ada. Dengan demikian berakibat pada kinerja yang belum efektif dan efisien, kepuasan pasien, perawat dan pimpinan terhadap aktualisasi diri rendah. Apabila penugasan yang profe-sional diterapkan oleh seorang kepala ruang atau supervisor maka perawat akan menguasai masalah pasien mulai dari pengkajian sampai evaluasi tindakan keperawatan yang akan berakibat pada peningkatan kepuasan pasien.

Berdasarkan gambaran diatas maka perlu dibina dan dilakukan pendampingan dengan memberikan pengetahuan tentang manajemen keperaatan yang berupa peran dan fungsi pimpinan keperawatan dan bagaimana cara mengaplikasikan ketrampilan tersebut.

\section{Identifikasi dan Perumusan Masalah}

Rumah Sakit PKU Muhammadiyah Surakarta dengan BOR yang tinggi menggambarkan jumlah pasien yang tinggi untuk meningkatkan kepuasan pasien harus mengembangkan pengelola-anya yaitu dengan meningkatkan pendidikan kepala ruangnya baik formal maupun informal. Kondisi saat ini adalah kepala ruang 80\% berlatar belakang D III keperawatan dimana sangat minim pengetahuan tentang manajemen kepera-watannya. Sehingga timbul suatu masa-lah yaitu masih kurangnya pengetahuan tentang manajemen keperawatan pada kepala ruang akan berpengaruh terhadap pengelolaan terhadap staf keperawatan di tingkat ruang yang akan berdampak terhadap kinerja yang diberikan pada pasien.
Kepala ruang dan supervisor ruang merupakan manajer lini pertama dalam rumah sakit yang akan menggerakan stafnya dalam mencapai tujuan rumah sakit. Manajer lini pertama ini mempu-nyai peran dan fungsi manajerial yang berbeda dengan manajer lain yang lebih tinggi atau sejajar dengannya. Untuk mencapai kepuasan klien terhadap asuhan keperawatan yang diberikan oleh staf keperawatan pengaruh kepemimpin-an kepala ruang sangat besar.

Dampak tersebut adalah apabila belum diterapkan metode asuhan keperawatan yang profesional oleh kepala ruang , maka perawat sebagai pelaksana pemberian asuhan keperawatan akan menguasai sebagian masalah pasien saja, apabila timbul masalah yang lebih komplek dari pasien, perawat tidak bisa memecahkannya. Dengan profesionalismenya pimpinan keperawatan, akan membantu perawat pelaksana dalam meningkatkan kualitas asuhan kepera-watan yang lebih profesional, perawat akan lebih bisa memecahkan masalah pasien secara kompleks sehingga pasien akan puas dengan pelayanan asuhan keperawatan yang diberikan. Tingkat kepuasan pasien yang tinggi menunjukan kinerja perawat dan kepala ruang yang makin baik. Berdasar masalah tersebut maka perlunya diadakan pendidikan informal melalui pembinaan dan pendampingan dalam bentuk pelatihan manajemen keperawatan tentang peningkatan pengetahuan peran dan fungsi pimpinan keperawatan, pendam-pingan penerapan ketrampilan peran dan fungsi pimpinan keperawatan di rumah sakit PKU Muhammadiyah Surakarta. Melalui pembinaan dan pendampingan kepada pimpinan keperawatan di rumah sakit tersebut akan mengakibatkan peningkatan pengetahuan dan kete-rampilan dalam pengelolaan manajemen keperawatan. 


\section{Tinjauan Pustaka}

Setiap perawat tanpa kecuali harus mempunyai peran dan fungsi sebagai seorang pemimpin (sebagai top manjer, sebaagai low manajer atau sebagi perawat pelaksana yang kan memimpin pasien dan keluarganya) Sebagai pelaksana keperawatan perawat harus mampu berperan dan berfungsi sebagai pemimpin terhadap pasien dan keluarganya. Sedangkan perawat yang duduk sebagai kepala ruang harus mampu mengelola keperawatan di tingkat ruangan yang dipimpinnya.

Kepala bidang keperawatan sebagai top manajer mempunyai peran dan fungsi sebagai pemimpin ditingkat topmanajer yang mempunyai perbedaan dengan kepala ruang sebagai low manaje (manajer lini pertama). Kepala ruang sebagai low manajer mampu menempatkan dirinya terhadap peran dan fungsi manajemen yang diembannya. Menurut Gillies (1994), manajer lini pertama adalah kepala ruang yang dalam fungsinya bertugas mengarahkan, mengkoordinasi, dan mengevaluasi secara langsung pada staf keperawatan.

Kepemimpinan merupakan inti dari manajemen , karena seorang pemimpin adalah pembuat keputusan /decision maker dalam suatu organisasi. Demikian juga dalam lingkup keperawatan khususnya peran pemimpin sebagai pembuat keputusan sangat mempunyai arti dalam kualitas upaya pelayanan keperawatan. Pengetahuan tentang kepemimpinan itu sendiri serta proses dan jenis kepemimpinan akan sangat membantu seorang kepala ruang dalam pembuatan kebijakan di ruangan, oleh karena itu pengetahuan kepemimpinan merupakan fundamen penting dalam pelayanan keperawatan di tingkat ruangan.

Beberapa definisi dan pengertian kepemimpinan yang dikemukakan oleh para ahli. Tetapi pada dasarnya intinya adalah sama yaitu ; Kepemimpinan adalah proses mempengaruhi orang lain untuk mencapai tujuan organisasi ( Gillies, 2001). Menurut Bennis dalam Kartono, (1998) Kepemimpinan adalah proses yang menyebabkan seseorang yang dipimpin bertingkah laku menurut suatu cara tertentu. Sedangkan menurut Tead kepemimpinan adalah kegiatan mempengaruhi orang lain agar mereka mau bekerjasama untuk mencapai tujuan yang diinginkan. Tanggung jawab pertama kepala ruang sebagai pemimpin adalah pemberian asuhan keperawatan yang efektif dan sesuai harapan klien melalui usaha staf keperawatan dan pengelolaan staf keperawatan yang berhubungan dengan tugas sebagai pemberi asuhan keperawatan.

Proses kepemimpinan merupakan suatu kegiatan dimana seorang pemimpin akan menjalankan peran dan fungsinya. Peran manajerial yang harus diaplikasikan oleh seorang pemimpin ketika menjalankan kepemimpinannya meliputi peran antar pribadi, peran pembuatan keputusan, peran informasional dan peran pembicara. Fungsi manajerial yang harus diaplikasikan ketika seorang pemimpin menjalankan kepemimpinanya adalah fungsi planning, fungsi organising, fungsi actuating dan fungsi controlling. Semua komponen yang ada dalam peran dan fungsi manajerial tidak bisa dipisah-pisahkan dalam mengaplikasikanya, sebab senua saling terkait dan saling mempengaruhi.

\section{Tujuan dan Manfaat}

a. Tujuan Umum

Tujuan umum dari pelatihan ini adalah memberdayakan pimpinan keperawatan dalam menjalankan peran dan fungsinya (kepala ruang dapat menerapkan manajemen keperawatan sesuai tingkat manajerialnya).

b. Tujuan Khusus.

1) Meningkatkan pengetahuan pimpinan keperawatan 
2) Meningkatkan ketrampilan pimpinan keperawatan

3) Mengaplikasikan pengetahuan dan ketrampilan melalui pembinaan dan pendampingan

c. Manfaat Jangka Panjang

Manfaat jangka panjang dari kegiatan ini adalah out came dari sistem kinerja di rumah sakit yaitu meningkat-kan mutu rumah sakit, meningkatkan pemberdayaan sumber daya manusia keperawatan, menambah pengetahuan kepala ruang, meningkatkan kepuasan kerja perawat, meningkatkan kepuasan pasien (memperpendek hari perawatan pasien, meminimalkan biaya rawat pasien, kenyamanan pasien dsb ).

d. Manfaat Jangka Pendek

Manfaat jangka pendek dari kegiatan ini adalah mendapatkan informasi baru tentang manajemen keperawatan, memperoleh keahlian tentang cara melaksanakan tugas yang sesuai (cara superviisi, membuat jadwal dsb), memperoleh kepercayaan disi untuk bekerja.

\section{Kerangka Pemecahan Masalah}

Masalah Kurangnya pengetahuan tentang manajemen keperawatan pada pimpinan keperawatan di RS PKU Muhammadiyah Surakarta merupakan masalah terstruktur sehingga masalah tersebut merupakan salah satu dari beberapa masalah di Rumah sakit yang sudah diidentifikasi. Berdasar pembicaraan dengan bagian diklat maka dipilih alternative pemecahan masalah dengan memberikan pelatihan terhadap kepala ruang. Dasar dari pemilihan alternative tersebut menggunakan metoda PEARL factor yaitu mempertimbangkan penyelesaian masalah melalui kesesuaiannya (Appropriateness),
Ekonomisnya (Ekonomic Feasibility), dapat diterima (acceptability), tersedianya sumber (Resourcers aviability) dan legalitas terjamin (legality).

\section{Khalayak Sasaran Antara Strategis}

Khalayak sasaran antara yang perlu dilibatkan dalam pengabdian masyarakat penerapan IPTEKS ini yaitu pimpinan keperawatan yang terdiri dari kepala bidang Perawatan, kasie keperawatan, supervisor keperawatan, kepala ruang dan koordinator shif.

\section{Keterkaitan}

Pelatihan manajemen keperawatan merupakan salah satu bentuk pengabdian masyarakat yang merupakan sub sistem dari Tri Darma Perguruan Tinggi. Manfaat Kegiatan ini bagi institusi Pendidikan menambah angaka kumulatif bagi dosen, menambah angka kumulatif publikasi ilmiah dan keuntungan bagi Rumah sakit adalah meningkatkan pengetahuan dan kompetensi manajerial bagi pimpinan rumah sakit yang berdampak pada meningkatnya kualitas pelayanan di RS PKU Muhammadiyah Surakarta.

\section{METODE KEGIATAN}

Metode kegiatan dalam pelatihan ini adelah melalui ceramah, simulasi, pemecahan kasus dan demonstrasi (penerapan langsung di ruang), uraian secara terinci tentang metode dapat dilihat pada tiap tahap kegiatan. 
Tabel .1

Materi Pelatihan Manajemen Keperawatan

\begin{tabular}{|c|l|l|l|l|}
\hline $\begin{array}{c}\text { Tahapan } \\
\text { Kegiatan }\end{array}$ & \multicolumn{1}{|c|}{ Kegiatan } & Metode & Waktu & Keterangan \\
\hline I & Pretes & $\begin{array}{l}\text { Pengisian } \\
\text { Kuis, } \\
\text { kuesioner, } \\
\text { diskusi dan } \\
\text { praktik } \\
\text { simulasi }\end{array}$ & 4 jam & \\
\hline II & $\begin{array}{l}\text { Pelatihan Teori } \\
\text { tentang peran dan } \\
\text { fungsi pimpinan } \\
\text { keperawatan }\end{array}$ & $\begin{array}{l}\text { Ceramah } \\
\text { dan tanya } \\
\text { jawab }\end{array}$ & $\begin{array}{l}2 \text { jam x 5 } \\
\text { hari }\end{array}$ & $\begin{array}{l}\text { Rancangan } \\
\text { lebih lanjut } \\
\text { dengan } \\
\text { POA }\end{array}$ \\
\hline III & $\begin{array}{l}\text { Pelatihan praktik } \\
\text { menjalankan } \\
\text { fungsi } \\
\text { manajemen }\end{array}$ & $\begin{array}{l}\text { Praktik, } \\
\text { demonstrasi, } \\
\text { di ruang } \\
\text { rawat inap }\end{array}$ & $\begin{array}{l}2 \text { jam x } \\
6 \text { hari }\end{array}$ & $\begin{array}{l}\text { Rancangan } \\
\text { lebih lanjut } \\
\text { dengan } \\
\text { POA }\end{array}$ \\
\hline IV & $\begin{array}{l}\text { Pendampingan } \\
\text { praktik klinik } \\
\text { langsung di tiap } \\
\text { bangsal rawat } \\
\text { inap }\end{array}$ & $\begin{array}{l}\text { Pengarahan, } \\
\text { evaluasi }\end{array}$ & $\begin{array}{l}2 \text { jam x } \\
6 \text { hari }\end{array}$ & \\
\hline
\end{tabular}

\section{Rancangan Evaluasi}

Evaluasi jangka pendek daari pelatihan ini adalah dengan cara mengukur peningkatan pengetahuan peserta pelatihan yaitu pimpinan keperawatan yang terdiri dari Kasie, kepala ruang, supervisor dan koordinator, dengan membandingkan nilai antara pre test dengan post test di tiap kompetensi dan nilai secara keseluruhan (kesatuan) Evaluasi jangka panjang dengan menilai dari penerapan pengetahuan perawat melalui : Pengukuran kepuasan kerja perawat dan pengukuran kepuasan pasien serta kinerja perawat dan pimpinan yang bisa dilakukan pada kegiatan lanjutan.

Rancangan Evaluasi teori berupa soal atau kuis dengan multiple coise, serta pertanyaan terbuka yang terstruktur dengan katagori baik apabila mampu menjawab lebih dari 80\% pertanyaan, sedang apabila mampu menjawab 65 sampai $79 \%$ pertanyaan dan buruk, apabila kurang dari 65\%. Rancangan evaluasi praktikum berupa urutan pelaksanaan prosedur yang terdiri dari 20 uraian. Katagori penilainya adalah baik, apabila mampu melakukan 75\% lebih prosedur, sedang apabila mampu melakukan 65 sampai $75 \%$ prosedur dan buruk apabila dibawah 65\%.

\section{Pentingnya Pembinaan dan Pendam- pingan}

Beberapa pimpinan keperawatan di rumah sakit mempunyai latar belakang sarjana keperawatan, dengan latar belakang tersebut pimpinan keperawatan sudah mendapatkan ilmu tentang manajemen keperawatan. Selain itu sebagian pimpinan keperawatan sudah menempuh pendidikan informal tentang menejemen keperawatan. Gambaran tersebut menunjukkan bahwa seharusnya mereka mampu mengaplikasikan ilmu pengetahuan yang sudah mereka dapatkan tetapi pimpinan keperawatan dalam mengaplikasikan ilmu tersebut membutuhkan dukungan, pembinaan dan pendampoingan tentang bagaimana cara mengaplikasikanya.

Marquis dan Huston (2000), menjelaskan bahwa penerapan model yang ideal dapat diklarifikasi dengan menggunakan penyamaan persepsi dan pembinaan melalui interaksi sosial dan proses pendidikan dengan pendekatan sosialisai pada karyawan di tempat mereka bekerja. Proses pendidikan dengan pelatihan yang berdampak pada peningkatan pengetahuan merupakan role model yang pasiv tetapi perceptor atau pembimbing klinik harus berperan sebagai role model karena akan berdampak menjadi peningkatan ketrampilan. Pembina atau pembimbing akan memberikan support emosional dan memotivasi perawat untuk bekerja.

Peran dari pembimbing atau mentor adalah sebagai berikut: model, envisioner, energiser, supporter, standart prodder, teacher coach, feedback giver, eye opener, door opener, idea bouncer, problem solver, carrer conselor, challenger. (Marquis dan Huston, 2000; Huber, 2002). 


\section{Kepala Ruang Sebagai Pemimpin}

Kita bahas salah satu contoh kepemimpinan dalam keperawatan. Pada dasarnya semua perawat adalah pemimpin, dimanapun dia berada baik sebagai top manajer sampai dengan pelaksana kepe-rawatan. Kepala ruang adalah pemimpin terdepan di sebuah rumah sakit. Menurut Gillies (1995), kepemimpinan keperawatan yang paling nyata dan mudah untuk dianalisa ada dalam penampilan/pelaksanaan manajer lini pertama keperawatan. Kepala ruang sebagai manajer lini pertama mempunyai dua tugas. Tugas pertama adalah pemberian keperawatan yang efektif melalui usaha bawahannya, tugas kedua adalah memberi kesejahteraan fisik, emosional dan jabatan bagi ruangan yang dipimpinnya . Kepala ruang akan melaksanakan peran dan fungsi manajemen sesuai dengan tingkat hirarkhinya seperti memecahkan konflik di tingkat ruang, memotifasi staf ditingkat ruang dansebagainya. Uraian ini akan lebih jelas dibahas dalam peran dan fungsi manajerial kepala ruang.

\section{a. Peran Kepemimpinan}

Beberapa peran yang harus dijalankan oleh seorang pemimpin, baik duduk ditingkat top manajer, middle manajer maupun low manajer (kepala ruang), peranan tersebut adalah:

1) Peran antar pribadi, Seorang kepala ruang dalam menjalankan tugasnya harus bisa berhubungan dengan atasannya, stafnya maupun dengan tim kesehatan itu. hubungan yang baik dengan stafnya merupakan salah satu faktor yang dapat memotivasi staf untuk menjadi loyal pada atasan. Selain itu kepala ruang harus mampu berhubungan dengan orang lain di luar lingkungannya untuk menambah ilmu pengetahuan.

2) Peran informasi, sebagai seorang manajer di tingkat ruangan, kepala ruang akan dipakai sebagai pusat informasi di tingkap ruangannya, sehingga kepala ruang harus mampu mengembangkan dan menyaring informasi yang kemudian dapat memutuskan mana informasi yang harus disampaikan pada stafnya dan mana yang harus pada atasannya.

3) Peran pembuat keputusan, Dalam mengelola ruangannya kepala ruang harus mampu membuat keputusan tentang halhal yang berhubungan dengan manajemen ditingkat ruangan-nya, misalnya jumlah tenaga kerja yang dibutuhkan ruangannya, metode asuhan yang akan diterapkannya dan sebagainya.

4) Peran pembicara, arti dari peran pembicara yaitu kepala ruang harus mampu mewakili kelompoknya dalam mengemukakan suatu pendapat, atau dapat dikatakan bahwa kepala ruang harus representatif bagi ruangannya. misalnya bagaimana figur seorang perawat intensive care unit, perawat gawat darurat dansebagainya.

Menurut Mintzberg (1973), bidang peranan manajer adalah peran antar pribadi, peran informasional dan peran pembuatan keputusan. Peran Antar Pribadi (Interpersonale Role yaitu, dalam menjalankan peran antar pribadi seorang manajer akan berperan sebagai figurhead yaitu suatu peranan yang dilakukan untuk mewakili organisasi yang dipimpinnya secara formal. Dalam peran ini manajer dianggap sebagai symbol yang berhubungan dengan aktifitas personal misalnya; pengguntingan pita, pemukulan gong, membuka acara tertentu dan sebagainya, semua dilakukan dalam rangka mewakili organisasi yang dipimpinnya.

Peranan sebagai pemimpin (leader) juga merupakan bagian dari peran interpersonal manajer, dalam peranan ini manajer bertindak sebagai pemimpin. Apabila pemimpin tersebut seorang kepala bidang keperawatan maka ia akan melakukan hubungan interpersonal dengan staf yang 
berada dibawahnya dengan cara memotivasi, mengembangkan dan mengendalikan.

Di samping itu peran antar pribadi manajer juga dapat dikatakan sebagai pejabat perantara (Liaison Manajer), disini manajer berinteraksi baik dengan teman sejawat maupun dengan orang yang berada di luar lingkungan organisasinya. Sebagai contoh kepala bidang keperawatan akan berinteraksi dengan dokter, ahli gizi, administrasi dan dengan yang lainnya.

Peranan yang berhubungan dengan informasi (Informational Role) Mintzberg (1973), membagi peran informasional ini menjadi peranan yang lebih rinci yaitu sebagai monitor, sebagai dessiminator dan sebagai juru bicara. Sebagai monitor seorang manajer akan menerima dan mengumpulkan informasi, kemudian dari informasi tersebut manajer akan mengembangkan dirinya , merubah dirinya dan informasi tersebut dipakai sebagai salah satu dasar dalam pengambilan keputusan.

Di lingkungan keperawatan manajer keperwatan dalam menjalankan peran sebagai monitor adalah dengan cara mencari dan mendapatkan informasi tentang kemajuan pelaksanaan asuhan keperawatan, metode pemberian asuhan keperawatan dari staf yang ada dibawahnya. Di luar lingkungan keperawatan dari peran monitor ini manajer akan mencari dan mendapatkan informasi luar organisasinya tentang perkembangan dan mutu keperawatan misalnya tentang kepuasan pasien, rumah sakit pesaing, IPTEK yang berhubungan dengan kesehatan yang semuannya bermanfaat bagi organisasi yang dipimpinnya.

Pada akhirnya sebagai informasional role manajer akan menyaring dan menganalisis semua informasi tersebut kemudian dipilih mana yang diperlukan, mana yang harus disampaikan pada atasanya, mana yang harus disampaikan pada bawahannya dan mana yang tidak perlu disampaikan. Menurut Thoha (1996) peran ini disebut peran dessiminator yaitu memberikan informasi dari luar ke dalm organisasinya.

Untuk kepentingan organisasinya manajer akan bertindak atas nama organisai dalam memberi informasi ke luar organisasi yang peran ini disebut sebagai juru bicara. Menurut Thoha (1996), beda peran dessiminator dan peran juru bicara adalah dari pemberian informasinya yaitu kedalam organisasi dan keluar organisasi.

Peran pembuat keputusan (Decisional Role) peran yang berhubungan dengan pembuatan keputusan merupakan peran manajerial yang paling penting, pembuatan keputusan terkait dengan strategi di dalam organisasi yang dipimpinnya sehingga satu sama lain sulit untuk dipisahkan. Menurut handoko (1996), antara strategi dan proses terjadinya suatu keputusan harus signifikan dan berhubungan, kemudian beliau juga menyimpulkan pendapat Mintzberg (1973), bahwa tugas manajer yang paling banyak adalah pembuatan strategi dan harus terlibat secara substansial di dalam setiap pembuatan keputusan organisasinya.

Tiga alasan mengapa manajer harus berperan dalam pembuatan keputusan menurut Handoko (1996), yaitu : Secara otoritas formal manajer adalah satu-satunya yang terlibat dan harus memikirkan tindakan -tindakan yang penting dan baru dalm organisasinya, sebagai pusat informasi, manajer dapat memberikan jaminan atas keputusan yang terbaik yang mencerminkan pengetahuan yang terbaru dan nilai-nilai organisasi, keputusan yang strategis akan lebih mudah diambil secara terpadu dengan adanya satu orang yang dapat melakukan kontrol semuannya.

\section{b. Fungsi Pimpinan Keperawatan}

Seperti fungsi dalam manajerial yang lain maka fungsi dari kepala ruang juga meliputi komponen-komponen yang sama yaitu Planing, Organising, Actuating dan Controling. Pengorganisasian yang dilakukan pimpinan meliputi kewenangannya, 
tanggung jawabnya, pendelegasian tugas termasuk pengorganisasian perawatan di tingkat ruang dalam memberikan asuhan keperawatan. Misalnya menentukan metoda tim di ruanganya.

Fungsi pengarahan, dalam menjalankan fungsi pengarahan kepala ruang akan melakukan kegiatan supervisi terhadap pelaksanaan asuhan keperawatan, bimbingan terhadap staf, mengkoordinasi dan memotivasi staf keperawatan. Fungsi pengarahan ini adalah merupakan fungsi dari kepemimpinan seorang kepala ruang secara menyeluruh diantaranya, bagaimana gaya kepemimpinanya, bagaimana mengelola konflik dansebagainya. Fungsi pengendalian dilakukan oleh kepala ruang dengan cara memantau kinerja, membandingkan dengan standar, dan mengoreksi bila ada penyimpangan yang terjadi di tingkat ruangan. Fungsi pengendalian atau kontroling ini dilakukan mulai dari perencanaan sampai evaluasi, Contohnya mengevaluasi kinerja staf, mengevaluasi dokumentasi keperawatan dalam 1 bulan terakhir setelah pelatihan dansebagainya.

\section{Fungsi Manajemen Keperawatan}

Robins (1996) menulis tentang fungsi manajemen yang dapat disimpulkan bahwa fungsi manajemen adalah fungsi perencanaan, fungsi pengorganisasian, fungsi kepemimpinan dan fungsi pengawasan. Fungsi manajemen terdiri dari beberapa komponen , yang menurut teoritisi sedikit berbeda dalam penyusunan dan pengembangannya, tetapi pada dasarnya intinya adalah sama. Menurut Swamburg (1993) dalam keperawatan fungsi manajemen terdiri dari perencanaan atau planning. pengorganisasian atau organizing, pengaturan staf atau stafing, kepemimpinan atau leadership dan pengendalian atau controlling .
Perawat sebagai manajer baik duduk di tingkat kepala bidang , kepala seksi, kepala ruang, ketua tim ataupun perawat pelaksana, harus melaksanakan fungsi-fungsi manajemen untuk memberikan pelayanan keperawatan kepada pasien, keluarga dan masyarakat.

a. Tahap Perencanaan, Perencanaan merupakan tahap awal dalam fungsi manajemen menurut Fayol dalam Swamburg (1993) definisi dari perencanaan adalah membuat rencana tindakan untuk memberikan pandangan ke depan . Dan menurut Swanburg (1993) perencanaan adalah fungsi administrative yang menempatkan beban resiko terhadap pembuatan keputusan dan pencegahan masalah. Perencanaan di keperawatan merupakan tugas dari kepala bidang keperawatan atau kepala devisi keperawatan dan kepala ruang untuk membuat perencanaan di tingkat manajerialnya kemudian diusulkan ke pimpinan diatasnya.

b. Pengorganisasian, organisasi merupakan suatu wadah untuk melaksanakan kegiatan, yang didalamnya terdapat pembagian tugas atau job description untuk mencapai tujuan organisasi. Pengorganisasian dalam keperawatan bermacam-macam bergantung pada konsep yang akan diterapkan. Pengorganisasian keperaatan di sebuah rumah sakit ada berbagai tingkatan atau hirarkhi seperti di tingkat bidang keperawatan, di tingkat ruang rawat. Pengorganisasian di tingkat low manajer atau di tingat ruang disebut metoda penugasan atau model praktik, contohnya model keperaatan primer, model tim, model fungsional dansebagainya.

c. Pelaksanaan kegiatan/Actuating, yang termasuk dalam actualing diantaranya pengarahan , kepemimpinan , motivasi 
dan lainnya. Kegiatan ini merupakan tahap ketiga dari fungsi manajemen yang dihubungkan dengan fungsi actuating. Salah satu contoh kegiatan ini adalah fungsi pengarahan yang bertujuan untuk mengukur kualitas penempatan , menemukan dan memperbaiki masalah serta mencegah penyimpangan dan modifikasi kegiatan yang sudah direncanakan untuk mencapai tujuan yang telah ditentukan. Komponen lain pada bagian ini akan dibahas lebih lanjut pada bab selanjutnya.

d. Pengawasan/Controling, Fungsi pengawasan sangat terkait erat dengan komponen lain terutama fungsi actuating, kedua fungsi manajemen ini saling tergantung. Misalnya seorang kepala ruang melaksanakan peran kepemimpinannya (fungsi actuating) dengan cara supervisi (controlling). Fungsi pengawasan dilakukan dengan membandingkan antara styandar atau perencanaan dengan pelaksanaan

\section{Uraian Tugas Kepala Ruang}

Uraian Tugas Kepala Ruang terdiri dari tahap perencanaan sampai evaluasi. Uraian tugas pada tahap perencanaan meliputi; menunjuk ketua tim yang bertugas di ruangan masing-masing, mengikuti serah terima dari shif sebelumnya, mengidentifikasi tingkat ketergantungan klien, mengidentifikasi jumlah perawat yang dibutuhkan berdasarkan aktifitas dan kebutuhan, mengatur penugasan atau penjadualan, merencanakan strategi pelaksanaan keperawatan, bersama dokter melihat kondisi klien kemudian mendiskusikan tindakan medisnya, pengobatannya, tindakan keperawatannya, mengatur dan mengendalikan asuhan keperawatan, membantu pengembangan staf melalui pendidikan dan pelatihan.
Uraian tugas pada tahap pengorganisasian meliputi, merumuskan metode atau sistem penugasan yang digunakan, merumuskan tujuan sistem atau metode penugasan, membuat rincian tugas ketua tim dan anggota tim, membuat rentang kendali misalnya kepala ruang membawahi 3 tim dan ketua tim membawahi 2 sampai 3 orang pelaksana, mengatur dan mengendalikan logistik ruangan, mendelegasikan tugas bila tidak berada di tempat atau ruangan, melakukan identifikasi masalah dan cara penanganannya.

Uraian tugas pada saat pengarahan, memberikan pengarahan tentang penugasan kepada ketua tim, memberikan pujian terhadap staf yang melaksanakan tugas dengan baik, memberi motivasi dalam meningkatkan pengetahuan, ketrampilan dan sikap, melibatkan bawahan sejak awal sampai akhir kegiatan, memberi teguran pada bawahan yang melakukan kesalahan, meningkatkan kerjasama dengan tim kesehatan lain.

Uraian tugas pada tahap pengawasan meliputi; melalui komunikasi mengawasi dan berkomunikasi secara langsung dengan ketua tim maupun pelaksana mengenai asuhan keperawatan yang diberikan pada klien, melalui supervisi mengamati langsung dan membatasi masalah yang terjadi, mengevaluasi upaya atau kerja pelaksana dan membandingkan dengan rencana keperawatan yang telah disusun bersama ketua tim.

\section{METODE PELAKSANAAN}

Pelatihan peran dan fungsi kepala ruang dilaksanakan di aula RSU PKU Muhammadiyah Surakarta pada tanggal 15 sampai 18 April 2010, pelatihan berlangsung mulai pukul 0800 s.d 14.30. Jumlah peserta pelatihan ada 28 orang yang terdiri dari kepala ruang, ketua tim, supervisor, kasie dan kepala bidang perawatan. Semua peserta 
mengikuti jalanya pelatihan mulai dari awal sampai akhir. Pembinaan aplikasi peran dan fungsi kepala ruang dilaksanakan pada tanggal 19 sampai 25 April 2010, mulai jam 0900 sampai jam 14 00. Pembinaan di ruang rawat inap diikuti kepala ruang, ketua tim dan perawat asosiet.

Peserta pelatihan mempunyai masa kerja terendah 9 tahun dan masa kerja terlama 12 tahun. Rata-rata masa kerja 10,5 tahun. Jumlah peserta pelatihan yang menjabat sebagai kepala bangsal ada 12 orang, 10 ketua tim , 3 orang penyelia atau supervisor serta 3 orang kasie keperawatan dan 1 orang kepala bidang keperawatan.

\section{Hasil Kegiatan}

Kegiatan Pelatihan dimulai dengan pembukaan yang didalamnya berisi sambutan dari pihak rumah sakit PKU Muhammadiyah dan dari pihak prodi keperawatan UMS. Kemudian sebelum materi disajikan semua peserta mengikuti pretes. Setelah diberikan pengetahuan tentang peran dan fungsi kepala ruang melalui ceramah, diskusi dan simulasi, selanjutnya semua peserta mengikuti postes.

Nilai pretes paling rendah 40 dan yang paling tinggi 72, dengan rata-rata nilai pretes 54,24 . Nilai postes paling rendah 68 dan yang paling tinggi 92. Rata-rata nilai postes adalah 82,23. Nilai postes tertinggi adalah 92 atas nama Istiqomah AMK. Sejumlah 28 peserta yang mengikuti pelatihan ada 3 peserta yang tidak mengikuti pretes dan postes. Hasil kegiatan pelatihan kepemimpinan dalam keperawatan secara kualitatif menunjukan adanya peningkatan pengetahuan kepala ruang tentang materi yang diajarkan hal ini ditunjukan dengan pemecahan masalah yang ada di bangsal saat dilakukan diskusi setelah pelatihan dibandingkan dengan reaksi saat penggalian tingkat pengetahuan diawal pelatihan.

\section{Pembahasan}

Hasil kegiatan pelatihan peran dan fungsi kepala ruang tentang aplikasi dalam kepemimpinan secara kualitatif menunjukan adanya peningkatan pengetahuan peserta pelatihan tentang materi yang diajarkan, hal ini ditunjukan dengan pertanyaan secara lesan yang bisa di jawab oleh peserta penyuluhan dibandingkan dengan reaksi saat penggalian tingkat pengetahuan diawal pelatihan. Selain itu juga ditunjukan dari meningkatnya nilai pada semua peserta pelatihan dari rata-rata kurang baik menjadi sangat baik.

Keberhasilan kegiatan pelatihan ini disebabkan kooperatifnya peserta mulai dari awal pelatihan sampai selesai, alasan dari aktifnya partisipasi peserta tersebut adalah keingintahuan peserta tentang peserta tentang ilmu manajemen keperawatan yang diajarkan, selain alasan itu ada beberapa penjelasan dari peserta bahwa penyegaran tentang ilmu manajerial pada pimpinan keperawatan penting dan sebaiknya dilakukan secara periodik.

Ketrampilan peserta ketika praktik menjalankan peran dan fungsi kepala ruang secara simulasi juga menunjukan perbaikan, hal ini ditunjukan oleh demonstrasi dari semua peserta setelah selesai pelatihan. Peserta bisa memperagakan lebih baik dibanding diawal pelatihan.

Evaluasi secara kuantitatif dilakukan dengan menjawab soal isian sederhana melalui pretes dan postes yang menunjukan peningkatan pengetahuan dilihat dari nilai yang meningkat. Rata-rata nilai sebelum pelatihan adalah 54 dan sesudah pelatihan adalah 82. Peserta yang mempunyai nilai tertinggi ada dua orang yaitu adalah Diyah dari ruang kebidanan dengan nilai 96 dan Istiqomah dari ruang rawat inap multazam dengan nilai 92. Menurut Notoatmodjo (1996) Kegiatan proses belajar bisa terjadi dimana saja, melalui penyuluhan kesehatan 
seorang akan belajar dari tidak tahu menjadi tahu. Sedangkan menurut Effendy (1995) pendekatan edukatif akan dapat memacu perkembangan potensi. Pendidikan kesehatan adalah pendekatan edukatif untuk meningkatkan ketrampilan pemecahan masalah pada sekelompok orang yang membutuhkan informasi.

\section{SIMPULAN DAN SARAN}

\section{Simpulan}

Kepala ruang merupakan ujung tombak pelaksanaan pelayanan dan asuhan keperawatan, agar tercipta pelayanan dan asuhan keperawatan yang berkualitas maka perlu pembinaan dan penyegaran yang terus menerus pada kepala ruang. Hasil pelatihan ini menggambarkan adanya peningkatan pengetahuan dan ketrampilan tentang aplikasi peran dan fungsi kepala ruang. Nilai setelah pelatihan menjadi lebih baik dibanding sebelum pelatihan

\section{Saran}

Berdasarkan kesimpulan diatas penting dilakukan pelatihan tentang peran dan fungsi kepala ruang di rumah sakit yang kemudian diharapkan untuk diaplikasikan di ruang rawat inap, sehingga diharapkan terjadi peningkatan kualitas pelayanan dan asuhan keperawatan. Saran lebih lanjut untuk puskesmas adalah : diadakanya pelatihan terstruktur dan terjadual pada kader tetntang berbagai macam manajemen keperawatan, diadakanya perawat magang untuk praktik manajemen keperawatan dibawah pembinaan institusi pendidikan agar terjadi bimbingan langsung pada kepala ruang di rumah sakit, bekerjasama dengan institusi pendidikan untuk bersama-sama mengadakan pelatihan pada rumah sakit.

\section{PERSANTUNAN}

Kegiatan ini terlaksana karena dukungan dari berbagai pihak, untuk itu kami mengucapkan terimakasih sebanyakbanyaknya kepada : 1). Bapak Kepala Lembaga Pengabdian Masyarakat, yang telah memfasilitasi kegiatan pengabdian masyarakat ini; 2). Kepala bidang Keperawatan RSU PKU Muhammadiyah Surakarta yang telah berperan aktif mulai dari awal kegiatan sampai selesai.

\section{DAFTAR PUSTAKA}

Gillies, D.A. 2001. Nursing Management, A System Approach. 3th ed. Philadelphia: WB Saunder Company.

Huber,D. 2002. Leadership and Nursing Care management. 2th ed. Philadelphia: WB Saunder Company.

Kartono K. 1998. Pemimpin dan Kepemimpinan. Jakarta: PT Raja Grafindo.

Swanburg, R. 2000. Pengantar Kepemimpinan dan Manajemen Keperawatan untuk Perawat Klinis. Alih bahasa Samba. Jakarta: EGC.

Loverdge, C.E. dan Cumnings, S.H. 2002. Nursing Management on The New Paradigm. Maryland: An Aspen Publication.

Marquis BL and Huston, C.J. 2000. Leadership, Role, and Management. Justin in Mosby. Philadelphia, Lippincott. 